\title{
Enlightenment of Xi Jinping's Theory of National Rejuvenation on Ideological and Political Education of University Students
}

\author{
Hongxia Li \\ Education Department of Ideological and Political Theory \\ Beijing Sport University \\ Beijing China \\ e-mail: 1090532227@qq.com
}

\begin{abstract}
This paper carried out an analysis and overview of Xi Jinping's theory of national rejuvenation; the Chinese dream refers to the great rejuvenation of the Chinese nation and the essence of which lies in national prosperity, national rejuvenation and people's happiness, the socialism with Chinese characteristics is the implementation path of the Chinese dream. Four enlightenments on ideological and political education of university students were put forward: the Chinese dream shall be deemed as a basic clue for understanding modern Chinese history; the relationship between the Chinese dream and its implementation path equals to the relationship between ends and means; the relationship between the Chinese dream and its implementation steps equals to the relationship between qualitative and quantitative changes; analyzing the correctness of Chinese road by applying the principles of universality and particularity of contradiction, thereby enhancing university students' confidence regarding the theory, path and system of the socialism with Chinese characteristics.
\end{abstract}

Keywords-Ideological and Political Education of University Students; Xi Jinping; Chinese Dream; Chinese Road

\section{INTRODUCTION}

On November 15, 2012, Xi Jinping made his first appearance in front of Chinese and foreign reporters as the general secretary of the Central Committee of the Communist Party of China (CPC) with the new central collective leadership, addressing that "Our responsibility is to rally and lead the whole party and Chinese people of all ethnic groups to take up this historic baton and continue working hard for the great rejuvenation of the Chinese nation"i; later he put forward the phrase of Chinese dream, and elaborated the essence and implementation path of the Chinese dream on many occasions. His theory of national rejuvenation has profound and lasting guiding significance for the implementation of ideological and political theory course by teachers in colleges and universities, which

${ }^{\mathrm{i}}$ Xi Jinping: Speech at the Press Conference with the Newly Elected Members of the Standing Committee of the 18th CPC Central Committee Political Bureau, Xi Jinping: The Governance of China, Foreign Languages Press, 10th edition in 2014, 4 .

\author{
Liyuan Zhang \\ Education Department of Ideological and Political Theory \\ Beijing Sport University \\ Beijing China \\ e-mail: zhangly0209@163.com
}

embodied consciousness and undertaking of historical mission and national responsibility by the new leading group, revealed the common dream that the Chinese nation has been in hard pursuit of for centuries, and pointed out a direction and specific path for national development.

\section{OVERVIEW OF XI JINPING'S THEORY OF NATIONAL REJUVENATION}

\section{A. Chinese dream: the great rejuvenation of the Chinese nation}

On November 29, 2012, Xi Jinping led the Standing Committee of the Political Bureau to visit the "Road of Rejuvenation" exhibition held by National Museum of China; the exhibition clearly narrated and represented the hardship and exploration of Chinese people on the national salvation road in modern times with rich and detailed historical materials and venation. After the visit, the newly elected general secretary of the Party Central Committee Xi Jinping addressed an exciting speech, in which he briefly retrospected the history ever since modern China; he summed up the past, present and future of the Chinese nation with three lines of ancient poems respectively: "the past of Chinese nation can be said as "The impregnable pass and a long way as tough as iron", during which we suffered numerous hardship; "the present of Chinese nation may be called "The correct path of the world is vicissitudes", during which we experienced many vicissitudes; "the future of Chinese nation can be said as 'You will ride the wind and cleave the waves"' , which will be full of prospect. Then he revealed the connotation of the Chinese dream: "nowadays, people are discussing the Chinese dream, in my opinion, to realize the great rejuvenation of the Chinese nation is the greatest dream of Chinese nation in modern times"'iii. In May 2013, Xi Jinping elaborated the essence of the Chinese

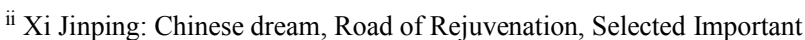
Documents Since the 18th CPC National Congress (Volume I), Beijing: Central Party Literature Press, 2014 edition, 83.

iii Publicity Department of the Communist Party of China: Readings of Important Speech Series of General Secretary Xi Jinping, Xuexi Publishing House and People's Publishing House 2014 edition, 25.
} 
dream during the joint written interview with the media from Trinidad and three Latin American countries--Tobago, Costa Rica and Mexico: "In the new historical period, the essence of the Chinese dream lies in national prosperity, national rejuvenation and people's happiness" ${ }^{\text {"iv }}$,national prosperity is the basic prerequisite of national rejuvenation and people's happiness; people can be stronger only when the nation becomes more prosperous, and people's happiness is the ultimate purpose of being a prosperous and strong country.

\section{B. The implementation path of the Chinese dream: the socialist road with Chinese characteristics}

On March 17, 2013, Xi Jinping emphasized on the first session of the 12th CPC National Congress: "We must take a Chinese road in realizing the Chinese dream...this road is hard won and has profound historical origins and an extensive realistic foundation, it is out of the great practice of reform and opening up for over 30 years in the past, out of the continuous exploration for over 50 years since the establishment of the People's Republic of China, out of the profound summary of the Chinese nation's development history for over 170 years since modern times, and out of the inheritance of the Chinese nation's long-standing civilization for over 5,000 years. "

The socialism with Chinese characteristics is an outcome of the relaying exploration of all previous CPC leading groups and a new accomplishment of localization of Marxism in China initiated during the new period of reform and opening up, Bo Yibo considered it as "Originated from Mao Zedong, accomplished by Deng Xiaoping"vi, Xi Jinping emphasized while presiding the first collective learning of the 18th Political Bureau of the Central Committee: "The first generation of central collective leadership centered by comrade Mao Zedong provided valuable experience, theoretical preparation and material basis for initiating the socialism with Chinese characteristics in the new period", the main content includes "the relationship among Deng Xiaoping theory, the important thought of the "Three Represents", scientific outlook on development, MarxismLeninism and Mao Zedong thought is persistence, development, inheritance and innovation"vii.

In many cases, the selection of path almost equals to death and birth of a party. The report of 18th CPC National Congress summarized: "the path is associated with the lifeblood of the Party, national prospect and destiny" viii. On

\footnotetext{
iv Xi Jinping: Xi Jinping: The Governance of China, Foreign Languages Press 2014 edition, 56.

${ }^{v}$ Xi Jinping: Xi Jinping: The Governance of China, Foreign Languages Press 2014 edition, 39-40.

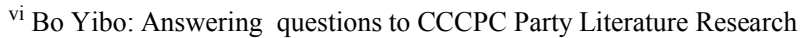
Office regarding exploration of Mao Zedong and performance of Deng Xiaoping, Literature of Chinese Communist Party 1995 (1).

vii Xi Jinping: Focus on upholding and developing socialism with Chinese characteristics, study, publicize and implement the spirit of the 18th CPC National Congress, Xi Jinping: The Governance of China, Foreign Languages Press, 2014 (10), 8-9.

viii $\mathrm{Hu}$ Jintao: unswervingly advance along the road of socialism with Chinese characteristics, strive for building a moderately prosperous society in all respects, Selected Important Documents Since the 18th CPC National Congress (Volume I), Central Party Literature Press, 2014 edition, 8.
}

January 5, 2013, Xi Jinping pointed out the following remarks at the seminar for studying and implementing the spirit of the 18th CPC National Congress for new members and alternate members of Central Committee: "the ultimate spirit of 18th CPC National Congress can be summarized as adhering to and developing the socialism with Chinese characteristics...the socialism with Chinese characteristics is a dialectical unity of scientific socialism theory logic and Chinese social development history logic, which is a scientific socialism that is rooted in Chinese land, reflecting wills of Chinese people, applying to development and progress requirements of China and the times, and it is the only way leading to building a comprehensive moderately prosperous society, accelerating socialist modernization and achieving the great rejuvenation of the Chinese nation"'ix .

The speech of Xi Jinping reflected his dialectical grasp of the socialism with Chinese characteristics, on the one hand it expressed the theoretical foundation of the socialism with Chinese characteristics, namely "the socialism with Chinese characteristics belongs to socialism rather than other isms, and the fundamental principles of scientific socialism must not be lost, otherwise it will no longer be socialism. The ism a nation implements depends on whether it can solve the historical task facing the country. History and reality both tell us that only socialism can save China, and only the socialism with Chinese characteristics can prosper China, this is from historical conclusion and the choice of people. "x On the other hand, he indicated the realistic foundation of the socialism with Chinese characteristics: "The development path of a country and nation inevitably possesses its own characteristics resulting from different historical tradition, cultural accumulation and fundamental realities of the country...the socialism with Chinese characteristics is rooted in the fertile soil of Chinese culture, reflecting wills of Chinese people, applying to development and progress requirements of China and the times...the unique cultural tradition, historical destiny and fundamental realities of the country all predestine that we must take a development path that suits our own characteristics. "xi Therefore, the preparation of path, principles and policies must conform to Chinese reality following the ideological line of seeking truth from facts of the Party. "To seek truth from facts, we must have a clear understanding and correct grasp of the fundamental reality of the country that China is still in the primary stage of socialism and will remain so for a long time...We shall endeavor to avoid any tendency that goes beyond reality and surmounts stage and being anxious for success, and we shall resolutely rectify any concept and practice that is conservative and stands still which falls

\footnotetext{
${ }^{\text {ix }} \mathrm{Xi}$ Jinping: Unswervingly adhere to and develop socialism with Chinese characteristics, Xi Jinping: The Governance of China, Foreign Languages Press 2014 edition, 21-22.

${ }^{x}$ The same as above, 22 .

${ }^{x i} \mathrm{Xi}$ Jinping: Make better propaganda and ideology work, Xi Jinping: The Governance of China, Foreign Languages Press, 2014 (10), 155-156.
} 
behind reality and ignores the objective facts that are in profound changes"xii.

\section{ENLIGHTENMENT ON IDEOLOGICAL AND POLITICAL EDUCATION OF UNIVERSITY STUDENTS}

$\mathrm{Xi}$ Jinping's theory of national rejuvenation enables Chinese people to be clearer about the struggle objective they have been pursuing for centuries in mind, be more resolute towards the implementation path and be more confident in the implementation steps. Teachers of ideological and political theory courses in colleges and universities should reflect on the bonding point of the Party's latest theory and various ideological and political theory courses of university students, exploring effective patterns of bringing Xi Jinping's theory of national rejuvenation into classes, teaching materials and mind, delivering their cognitional sublimation regarding this issue to university students through various channels, helping university students to comprehend the practical significance of $\mathrm{Xi}$ Jinping's theory of national rejuvenation from theoretical perspective, thereby enhancing their confidence regarding the theory, path and system of the socialism with Chinese characteristics.

\section{A. Deeming the Chinese dream as a basic clue for understanding modern Chinese history}

Fully learning modern Chinese history is the crux of comprehending Xi Jinping's theory of national rejuvenation, and to comprehend the Chinese dream we must understand the historical background since modern China. A profound historical background lies behind each national dream, the reason accounting for the Chinese dream's being different from the dreams of other countries relates to the historical context China has experienced from modern times. The Chinese nation possesses a history extending five thousand years and owning splendid ancient culture, it reached its heyday during Han and Tang dynasties, and gradually declined during Ming and Qing dynasties; after the Opium War in 1840 it fell into a semi-feudal society, and the northeast region was once descended to a colony of Japan. Not a single nation is willing to endure aggression and bullying from foreign nations, just as the lyric of the national anthem of the People's Republic of China: "China masses have met the day of all danger, indignation fill the hearts of our countrymen", achieving national independence and liberation and the great rejuvenation naturally become the greatest hope of an oppressed nation, which arises from the survival instinct. Since then, a lot of people with lofty ideals have been exploring and striving for independence and liberation of the Chinese nation and the path of the great rejuvenation: westernization movement, Hundred Days of Reform, saving the nation by education, saving the nation by engaging in industry and so on. All roads have been tried but they all failed, only the Chinese Communist Party led by Mao Zedong explored a revolutionary road of the socialism with Chinese characteristics and established an independent

\footnotetext{
xii Xi Jinping: Adhere to and make good use of the living soul of Mao Zedong Thought, Xi Jinping: The Governance of China, Foreign Languages Press, 2014 (10), 26.
}

New China by combining the general principles of Marxism with Chinese reality. History has proved that only socialism can save China.

As university students are the future of a nation and pillar of the state, teachers of ideological and political theory courses should emphasize the relationship between learning this course and comprehending the Chinese dream while teaching the course of "Compendium of Chinese Modern History". History is the memory of a nation and we can not be a forgetful nation, in that way we will lose our development direction by forgetting the past. University students should possess basic historical attainment and know the origin and development history of their nation; history has provided us with many painful lessons and valuable experience which will guide us toward a bright future. Compendium course teachers should apply diversified teaching methods to help students realize that the reason for China to embark on the path of socialism is the choice of history and choice of the people. The Chinese dream put forward by Xi Jinping can be described as a finishing touch, which is of great help to understand modern Chinese history; it revealed the common dream that the Chinese people have been in hard pursuit of for centuries and the most urgent historical task they are determined to solve--the Chinese dream, hence it is a principal line that runs through modern Chinese history, university students should take the Chinese dream as the most basic clue in comprehending modern Chinese history.

\section{B. Observing the Chinese dream and its implementation path from the relationship between ends and means}

$\mathrm{Xi}$ Jinping's speech regarding the Chinese dream and Chinese road embodied the dialectical unity between ends and means as well as targeting task and method. If realizing the Chinese dream is the struggle objective that the Chinese nation has been pursuing for over a century, then the implementation path of the Chinese dream--the socialist road with Chinese characteristics is the means to accomplish this great objective, the relationship between them resembles that between river crossing and bridge, building the socialism with Chinese characteristics is to realize the Chinese dream of the great rejuvenation of Chinese nation. Compared with the Chinese road, the Chinese dream is more accepted by the masses with functions of cohesive force. Many ordinary people would think that adhering to the socialism with Chinese characteristics is the matter of Marxist theorists and state leaders which does not matter them too much, but they will feel being concerned when mentioning the Chinese dream, for realizing the Chinese dream is the basis of realizing personal dreams; people can be stronger only when the nation becomes more prosperous, and they can enjoy happiness, a poor and weak country can not even guarantee the basic rights of its citizens. Therefore, the Chinese dream is a successful example of the popularization of Marxism with Chinese Characteristics. 
C. Observing the Chinese dream and its implementation steps from the perspective of the rule of quantitative and qualitative changes

While teaching the course of Introduction to the Basic Principles of Marxism, teachers of ideological and political theory courses should connect with the practical issue of the Chinese dream by combining dialectics. People often say "I have a dream", a dream is a dream which is the struggle objective to be realized and the qualitative change referred to in Marxist philosophy; realizing the Chinese dream of the great rejuvenation of the Chinese nation means pursuing qualitative changes of the Chinese nation in world status and developing situation. Qualitative change requires quantitative accumulation according to the dialectical relationship between quantitative and qualitative changes, which is accomplished by the staged and local partial qualitative changes in quantitative change process. Therefore, realizing the general qualitative change (namely the general objective) of the Chinese dream requires at least two major staged partial qualitative changes (namely sub-objective): the independence and liberation of the Chinese nation shall be realized firstly, and then the great rejuvenation of the Chinese nation can be realized. The first staged partial qualitative change took almost over a hundred year (1840-1949), which was accomplished by two staged partial qualitative changes (namely Sun's objective)--Xinhai Revolution led by Sun Zhongshan and new-democratic revolution led by Mao Zedong. After the founding of PRC, the great process of the second sub-objective (national rejuvenation) began to be realized. After the first thirty years of hard pioneering work and painstaking exploration, an industrial system with a complete category was built, which provides a solid material foundation and theoretical experience for finding a development path that suits for Chinese reality. After 1978, the second generation leader Deng Xiaoping of Chinese Communist Party made a strategic decision of reform and opening up, and determined a more specific "three-step" strategy (namely smaller objectives under Sun's objective) on the 13th CPC National Congress in 1987: the first step is to solve the problem of food and clothing by the end of the 1990s, the second step is initial realization of moderate prosperity by the end of the 20th century, and the third step is to basically realize modernization by the mid-21st century. The report of 15 th CPC National Congress in 1997 further detailed staged objectives and put forward the plan of "two centenary goals": to finish building a moderately prosperous society in all respects by the time the Communist Party of China celebrates its centenary in 2021; and to turn China into a modern socialist country that is prosperous, strong, democratic, culturally advanced, and harmonious by the time the People's Republic of China celebrates its centenary in 2049; and to finally realize modernization of socialism. Over the thirty years since reform and opening up, the national economy has achieved a continuous and steady growth with the total GDP amount soaring to the second place in the world. Today, we are ever closer to the second staged qualitative change.
Detailing of staged partial qualitative changes must be carried out in realizing the general qualitative change of the Chinese dream according to the rule of quantitative and qualitative changes, sub-objective must also be conducted in realizing the general objective of the primary stage of socialism in China; the decomposition of Sun's objective is the accumulation transiting from qualitative change to quantitative change. The deduction of the strategic thinking can enhance university students' confidence regarding the path, theory and system of the socialism with Chinese characteristics.

D. Enhancing university students' confidence regarding three aspects of the socialism with Chinese characteristics by applying the principles of universality and particularity of contradiction

While teaching the course of Introduction to the Basic Principles of Marxism, teachers of ideological and political theory courses should help university students to understand the philosophical basis of the socialism with Chinese characteristics, namely the principles of universality and particularity of contradiction. The universality of contradiction refers to the common problems encountered by many practical subjects, and the particularity of contradiction refers to individual problems that are different from other practical subjects encountered while solving common problems. As for all the nations and countries that have chosen the path of socialism, they must make clear what is socialism? What are the essential characteristics of socialism? This is an issue of direction that must be adhered to and a contradiction with universality that must be solved; otherwise it would no longer be a socialist country. However, China stepped on the path of socialism on the basis of being a semi-colonial and semi-feudal society, national capitalism did not get sufficient development under the collusion and exclusion of feudal economy, foreign capitalism and bureaucratic capitalism, the situation had a great gap from Marx's premise of highly developed productivity of scientific socialism; besides, China is a big country with a population of 1.3 billion people and annual newborn population of about 20 million, which equals to increasing an Australian population per year; a series of problems including food, medical care, education, job search after 20 years old are brought about. This might be a nonexistent problem for other socialist countries, yet it is China's largest practical consideration; therefore it is a particular contradiction China needs to solve in International Communist Movement. According to the principle that universality resides in personality and generality is inseparable from individuality, the preparation of development path, principles and policies must conform to Chinese reality by combining the basic principles of socialism with the national conditions of China, which determines that China requires a long primary stage of socialism to develop diverse sectors of the economy to improve the backward productivity and catch up with the economic level of developed countries. Therefore, no country shall copy the full set of a foreign mode, it can only go its own way to find an own distinctive path of development. Through the above analysis, we can relieve 
some ideological confusion of college students regarding the development path of China, and dispel some doubts like "switch on the left light to make the right turn" while China is walking on the "capitalist path with Chinese characteristics".

\section{REFERENCES}

[1] Chen Jing, He Guangquan. A Review on the Study of Vocational Education in "the Eleventh Five Year Plan" [J]. Journal of Continuing Education School of Hebei University. 2014,04:65-69.

[2] Luo Hongyan. The Cause of Enrollment Plight of Higher Vocational Colleges in China [J].Adult Education, 2008,11:64-65.

[3] Luo Hongyan. The Study of Difficulties Faced by the CPC in Developing China's Higher Vocational Technical Education [J].Adult Education, 2011,(2).

[4] Luo Hongyan. The Study of Difficulties Faced by the CPC in Developing China's Higher Vocational Technical Education [J].Adult Education, 2011,(2).

[5] Liu Hong. Review on the 2014 Annual Conference of CSVTE[J]. The Chinese Society of Vocational and Technical Education, 2014,34:1319

[6] Luo Hongyan. Analysis on the Cause of Ineffective Education Policy of Vocational Education in China [J].Education and Vocation, 2008,27:16-17.

[7] Luo Hongyan. The Strategies for Promoting the Development of Higher Vocational Technical Education [J].Education Academic Journal.2010,(11).

[8] Luo Hongyan. The Construction of Practical Teaching System in Newly-established Higher Vocational Normal Colleges, 2009,05:4546.

[9] Lu Yang. The Study on the Cultivation of "Double-Certificated Teachers" in Higher Vocational Colleges of Henan Province [J].HUST (Huazhong University of Science and Technology).2012. 